\author{
Michał WALLNER
}

Maria Curie-Skłodowska University, Faculty of Political Science, Lublin, Poland

Artur KOKOSZKIEW ICZ iD

University College of Enterprise and Administration, Faculty of Social Sciences, Lublin, Poland

\title{
Maritime Piracy and Limitations of the International Law of the Sea
}

\section{Piractwo morskie i ograniczenia międzynarodowego prawa morza}

\section{- Abstrakt •}

Zasadniczym celem artykułu jest analiza definicji legalnej piractwa zawartej w art. 101 Konwencji Narodów Zjednoczonych o prawie morza. Jak wskazuje tytuł artykułu, fenomen piractwa morskiego jest rozważany wyłącznie przez pryzmat międzynarodowego prawa morza, co oznacza, że regulacje prawa krajowego pozostają poza zakresem analizy. Autorzy podejmują próbę interpretacji i krytycznej oceny odpowiednich przepisów prawa; ich intencją nie jest natomiast przytaczanie faktów związanych z przypadkami piractwa morskiego ani prezentowanie statystyk określających skalę tego zjawiska. Artykuł jest podzielony na sześć stosunkowo krótkich części. Kluczowe rozważania zawarte są w częściach 3-5, które odpowiadają stosownym przepisom Konwencji z Montego Bay. Części te dotyczą odpowiednio: definicji piractwa, wymogu celów osobistych oraz wymogu dwóch statków. Trzy pozostałe części artykułu stanowią: wstęp, tło historyczne i wnioski.

\section{- Abstract •}

The primary aim of this paper is to analyse the legal definition of piracy stipulated in Article 101 of the United Nations Convention on the Law of the Sea. As the title of the paper itself suggests, the phenomenon of maritime piracy is examined only from the perspective of international law of the sea, which means that state municipal laws remain beyond the scope of the analysis. The authors attempt to interpret and critically assess relevant legal provisions, rather than recount in detail facts related to cases of maritime piracy or present statistics describing the scale of this phenomenon. The article is divided into six relatively short sections. Key considerations are contained within sections 3-5, which cover the relevant provisions of the Montego Bay Convention. These sections deal, respectively, with the definition of piracy, the "private ends" requirement, and the "two-vessel" requirement. The remainder of the article is divided into introduction, historical background and conclusions. 
Słowa kluczowe: piractwo morskie; międzynarodowe prawo morza; Konwencja Narodów Zjednoczonych o prawie morza (Konwencja z Montego Bay); definicja legalna piractwa
Keywords: maritime piracy; international law of the sea; United Nations Convention on the Law of the Sea (Montego Bay Convention); legal definition of piracy

\section{Introduction}

"As the scene of the pirate's operations is the high seas, which it is not the right or duty of any nation to police, he is denied the protection of the flag which he may carry, and is treated as an outlaw, as the enemy of all mankind - hostis humani generis - whom any nation may in the interest of all capture and punish"'.

Pirates seem to be primarily characters from books or movies. However, as Elizabeth Nyman notes, "In recent years, piracy has leapt once again from the pages of the history books into the front pages of the newspaper. A phenomenon that fifty years ago had been assumed by many international legal scholars to have run its course by the early 1800s has returned to the world with increasing frequency" (Nyman, 2011, p. 863).

The primary aim of the present paper is to analyse the legal definition of piracy under the United Nations Convention on the Law of the Sea (UNCLOS) ${ }^{2}$. As the title of the paper suggests, piracy will be examined through the prism of international law of the sea, which means that state municipal laws are remain outside the scope of the analysis. Moreover, the authors attempt to interpret and critically assess relevant legal provisions, rather than recount mere facts or figures ${ }^{3}$.

The article is divided into six relatively short sections, with each substantive section focusing on one pertinent rule of the UNCLOS. Key considerations are contained within sections 3-5, which deal respectively with the definition of piracy, the "private ends" requirement, and, last but not least, with the "two-vessel" requirement. Three additional parts are introduction, historical background, and conclusions.

${ }^{1}$ Judge Moore in The Lotus Case in 1927; S.S. Lotus (Fr. v. Turk.), 1927 P.C.I.J. (ser. A) No. 10 (cited after: Beckman, 2011).

21982 United Nations Convention on the Law of the Sea, Open for Signature on 10 December 1982, Entered into Force on 16 November 1994, 1833 United Nations Treaty Series 397.

${ }^{3}$ However, one has to remember the scale of the problem. According to the data gathered by the International Maritime Bureau (IMB) in 2012, there were a total of 76 reports of piracy and sea robbery worldwide, of which 31 were attacks attributed to the Somali, involving 6 hijacked ships and $86 \mathrm{crew}$ members being held hostage (piracy figures as of 8 March 2012). See: IMB Piracy Reporting Centre, Piracy News \& Figures. 
While the authors are primarily concerned with de lege lata considerations, they also make some de lege ferenda remarks. The latter result from the authors' belief that the current piracy definition under the UNCLOS regime is somewhat obsolete and not fully effective. The authors are also convinced that changes to this definition need to be made to adjust it to the current expectations and conditions. Maritime piracy is a real problem in today's international economic relations and the law (in particular international law) should respond to such challenges, adapting to the expectations of trading participants (Shnider, 2013, p. 489-492).

\section{Historical Background}

It may be justified to assume that piracy has existed for as long as the seas were used for trade. As one author puts it, "The very first time something valuable was known to be leaving a beach on a raft the first pirate was around to steal it" (Gottschalk et al., 2000, p. 1). Academic literature is dominated by the view that piracy is a complex phenomenon: "Though piracy has been a problem for many societies, including that of the ancient Greeks and Romans, the heyday of piracy/ privateering is usually considered to have occurred during the $17^{\text {th }}$ and $18^{\text {th }}$ centuries. This was the time of noted pirates such as Sir Francis Drake, who made a fortune for himself and Queen Elizabeth of Britain, and Sir Henry Morgan, who sacked the Spanish settlement of Panama City and later became lieutenant governor of the English colony of Jamaica. Since there were constant eruptions of war between the European powers during this time, ships would be called into service as privateers to take ships in the name of their state. However, when the war would end, those same ships would continue to sack commercial transport, only now as pirates. Thus, privateering, a resource for a state at war, was the breeding ground for piracy, a scourge to that same state in times of peace" (Nyman, 2011, p. 864).

In response to the threat posed, coastal states were adopting rules aimed at suppressing piracy. At the outset, international regime on piracy existed only under customary law ${ }^{4}$. It should be noted that the coastal state has traditionally been

${ }^{4}$ There is still considerable terminological confusion in legal literature concerning the concepts of custom and customary law. Various terms are used in academic circles in this respect: custom, customary law, habit, uniform practice, usage, uniform rules of conduct (Trzciński, 1998, pp. 156-157). Jerzy Wiszniewski claims that the term "custom" signifies a rule of conduct that is not established by the state, but created through long-term practice of social relations on a certain territory or among a certain group of people. A custom rule becomes binding if the state equips it with a sanction expressly provided for by law or respected by court practice (Wiszniewski, 1977, 
given the opportunity to judge a pirate - if only it could catch him: "The original rationale for universal jurisdiction over pirates sprang from the locus of the crime - the high seas. No state had jurisdiction extending from its coastal waters into the common area of the high seas, and so every state was granted jurisdiction over pirates if it could catch them" (Kelly, 2013, p. 27).

Over the course of time, however, following the Second World War and the establishment of the United Nations (UN), the need for codification of international law emerged. There had been two attempts to codify the rules on international maritime piracy before success was finally achieved in 1958 in the form of the Geneva Convention of the High Seas (GHSC). The first attempt was made by the Committee of Experts for the Progressive Codification of International Law of the League of Nations which produced a proposal in 1926. Subsequently, the piracy rules were also the subject of the 1932 Harvard Draft Convention on Piracy (Jesus, 2003, pp. 385-386). The latter proposal became an important point of reference for the International Law Commission (ILC) whose work on codification of the law of the sea was reflected in the "Articles concerning the Law of the Sea with Commentaries" (1956).

As mentioned above, these developments finally culminated in establishment of the modern laws on piracy via the GHSC (Articles from 14 to 21), and subsequently the UNCLOS (Articles from 100 to 107). The current law on piracy contained in the UNCLOS was directly transplanted, verbatim, from the GHSC. "It is acknowledged that by the time the GHSC was drafted, piracy was considered an historical throwback and sections governing it were included as a matter of historical propriety rather than out of any genuine need. This was made clear in the $288^{\text {th }}$ meeting of the ILC (10 May 1955) where Scelle commented that issues of piracy and the slave trade were exceptional in modern times. Before the GHSC was drafted there were a number of unsuccessful attempts to codify customary law on piracy jure gentium. However, these attempts were considered to be de lege ferenda rather than merely a codification of the existing state of the law" (Paige, 2013, p. 144).

pp. 34-35). According to Stanisław Matysik, custom is a rule of conduct considered to be binding and established by long-term use in the given legal framework (Matysik, 1971, p. 91). In a similar vein, Józef Górski states that one is dealing with customary law when certain social relations are not regulated by law, but by principles created through long-term social practice and recognized by courts or state administration (Górski, 1964, p. 9).

5 Georges Scelle (19 March 1878-8 January 1961) was an international jurist and member of the United Nations International Law Commission. 
Since the adoption of the UNCLOS in 1982, international law in the field of vessel security was considerably expanded by the 1988 Convention for the Suppression of Unlawful Acts of Violence against the Safety of Maritime Navigations (SUA Convention). It has to be stated that the SUA Convention does not explicitly cover the crime of piracy and the offences it regulates do not overlap with the crime of piracy as defined under the UNCLOS (Middleton, 2009, p. 33). Nevertheless, while in the past politically motivated acts of violence or depredation against ships and persons aboard were - short of being piracy - left outside the scope of international regulations, they are now covered by Article 3 of the said SUA Convention (Jesus, 2003, p. 378).

In summary, from a historical perspective special attention should be paid to the importance of custom and customary law in shaping contemporary legal regulations in the field of maritime piracy.

\section{Definition of Piracy}

The legal definition of piracy has fluctuated throughout the centuries. As Kelly notes, "The heinous nature of the act [of piracy] usually meant pirates were subject to universal jurisdiction, but what constitutes the act itself has ranged from straightforward robbery at sea to, recently, violence at sea that includes engaging in acts of political protest. The modern trend of employing an expansive 'violent attacks at sea' definition is appealing because of its ability to account for a wide variety of conduct in a wide variety of contexts. But the consequences of such an approach include a risk of returning to past experiences where political expediency was prioritized over due process" (Kelly, 2013, p. 25).

Article 101 of the UNCLOS provides a definition of piracy according to which it consists in illegal acts of violence or detention or any act of depredation committed for private ends by the crew of a private ship, and directed against another ship on the high seas or outside the jurisdiction of any state. Wording of this provision was established by way of compromise; hence it is imperfect and lacks coherence. O'Connell maintains that the text is both tautologous and imprecise tautologous because it speaks of "illegal acts of violence" and imprecise because it offers no guidance as to what types of violence constitute piracy (O'Connell, 1982, p. 369). Clearly, the words "illegal acts of violence" may introduce slight ambiguity. One could ask under what system of law the acts in question must be "illegal" (Middleton, 2009, pp. 28-29). In the absence of an international agreement clarifying the concept, this illegality has to be determined by the courts of the state 
which seizes a pirate ship (Nandan, Rosenne, 1995, p. 201). Yet, sovereign states are not prosecuting piracy suspects with any regularity. Some research suggests that relatively few states have enacted comprehensive antipiracy laws that include a framework for exercising universal jurisdiction over pirate attacks (Dutton, 2012). One could also ask whether there is a significant difference between the use of the wording "acts of violence" (plural) and "act of depredation" (singular). A literal interpretation of these words would exclude a single murder at sea from the definition of piracy. However, it is the repudiation of all authority which seems to be the essence of piracy - not any specific types of acts that pirates commit. This view seems to be supported by Hall who claims that, as the specificity of piracy is its rejection of State authority it is not confined to depredations or particular acts of violence; he insists that a satisfactory definition "must expressly exclude all acts by which the authority of the State is not openly or by implication repudiated" (Hall, 1924, p. 311; Rothwell et al., 2010, p. 302).

As Jonathan Bellish observes, modern maritime piracy is not just simply robbery of a ship. "Historically, maritime piracy occurred entirely at sea, as the pirate ship approached the victim ship, boarded it, robbed it, and sailed away. Today, Somali piracy, which represents over half of contemporary global attacks more closely resembles an organized crime syndicate than the antics of Captain Jack Sparrow. Rather than simply robbing the victim ship, Somali pirates board a large merchant vessel and hold its cargo and crew hostage, reaping ransoms that averaged around \$5 million in 2011” (Bellish, 2013, p. 122).

In conclusion, one could state that effectiveness of the international legal regime dealing with piracy depends ultimately on sovereign states. Successful fight against maritime piracy requires all states to embrace their duty to share in the burden of prosecuting pirates, which means that all states must first pass the necessary domestic laws criminalizing maritime piracy (Dutton, 2012).

\section{The "Private Ends" Requirement}

As mentioned elsewhere, the definition of piracy has been the source of much controversy. The first point of contention is the meaning of the phrase 'private ends' in subsection (a) of article 101 of the UNCLOS. "This debate hinges on whether the phrase simply excludes acts conducted with state sponsorship or whether animo furandi is still a required element of crime, thus denying acts that are politically motivated as piracy. The ILC drafts have been used to argue that acts done with a political motivation cannot constitute piracy, but also to argue that animo furan- 
$d i$ is no longer necessary and that 'private ends' was used so that acts of hatred and vengeance were also covered by the definition" (Paige, 2013, pp. 145-146). Thus, the UNCLOS definition which specifies that pirates must be seeking private ends, ignores potential piracy with other objectives, such as political agendas or terrorism (Dowdle, 2015, p. 629).

Since pirates have traditionally committed plunder for acquisitive purposes, and violence against persons has been only secondary to that goal, the law of the sea has been preoccupied with the aspect of theft in piracy (O'Connell, 1982, p. 967). However, the definition provided by the UNCLOS clearly abandons this traditional concept. By introducing the notion of "private ends", it covers acts motivated, for instance, by feelings of hatred or revenge, and not merely by the desire for gain. In other words, the presence of intention to rob (animus furandi) is not required in this definition (Nandan, Rosenne, 1995, p. 197).

The condition that piracy must be committed for private ends stems probably from the distinction between real piracy and state-sponsored privateering of the $16^{\text {th }}$ and $17^{\text {th }}$ centuries (Bento, 2011, p. 119). In limiting the definition to acts committed for private ends, Article 101 of the UNCLOS excludes acts having political/public goals ${ }^{6}$. Thus arises the question about the possibility of effective defence before the court based on this excuse - for example a declaration of the captured pirate that he acted for the public good. This is, by the way, a common line of defence of Islamic terrorists. Therefore, one has to distinguish between the acts of genuine piracy and those acts of violence or depredation that are committed by, for example, environmentally-friendly groups in connection with their quest for marine environment protection or national liberation movements seeking a solution to their political problems. Sometimes their activities are marked by piracy. Thus, there are still some "grey areas" that make it difficult to make a clear distinction between an act committed for "private ends" and an act in pursuit of some politically-motivated goal. This is well exemplified by the practice of some rebel groups which rob or detain a ship and hold the crew for a ransom as a fundraiser scheme to finance their political activities (Jesus, 2003, p. 378).

${ }^{6}$ Politically-motivated acts of violence committed on the high seas or outside jurisdiction of any state may be seen as the subject of the 2005 Protocol to the SUA Convention. Article 4 of the 2005 Protocol provides that "Any person commits an offence within the meaning of this Convention (...) when the purpose of the act, by its nature or context, is to intimidate a population, or to compel a government or an international organization to do or to abstain from doing any act (...)". See: Protocol to the Convention for the Suppression of Unlawful Acts of Violence against the Safety of Maritime Navigations. 


\section{The "Two-Vessel” Requirement}

Another inconsistency inherent in the definition of piracy concerns the two-vessel requirement. On the one hand, subparagraph (a)(i) of Article 101 of the UNCLOS indicates that an attack against "another" ship is necessary for the attacker's action to fall within the scope of the piracy definition. On the other hand, under subparagraph (a)(ii) any attack against "a" ship amounts to piracy. If the latter provision was to be interpreted literally, it would mean that challenges by a ship's crew against their own master may fall under the Convention's definition (Nandan, Rosenne, 1995, p. 201). However, it is reasonable to state, especially having in mind the travaux préparatoires, that the piracy definition was not intended to and does not cover the one-ship situation (Jesus, 2003, p. 377). One has to bear in mind the general rule set out in Article 92 of the UNCLOS that a ship on the highs seas is subject to the exclusive jurisdiction of its flag state. Consequently, every act committed against a vessel navigating the high seas should be qualified in accordance with domestic laws, and not international law. Internal seizure of a ship clearly would not constitute piracy under this definition. Otherwise, there would be no distinction between piracy and mutiny/hijacking. Moreover, additional rationale for supporting the two-vessel requirement of Article 101 is that Article 100 imposes an obligation on all states to repress piracy, and "there are evident political dangers in demands for the delivery of persons who seize ships internally, as well as in the interference of foreign nations in the event" (O'Connell, 1982, p. 973).

\section{Conclusions}

Pirates are considered the common enemy of all mankind. "During ancient times, pirates raided villages, erected sea tolls, robbed vessels, kidnapped people for ransom, and extracted "protection" monies from coastal cities. States dealt with pirates in creative ways. Pompey gave pirates, who voluntarily surrendered, lands; the rest were put to death, Caesar slaughtered them, England ordered captured pirates to be immediately hung from the main-mast, The French condemned pirates to the torture of the wheel. Governments, without strong navies, utilized piracy as a means to attack one's enemies" (Doby, 2010, pp. 565-566).

As piracy still remains a considerable threat to maritime security, there seems to be a pressing need to, among other measures, review and further develop the existing international rules provided for in the UNCLOS. This revision of the Con- 
vention should entail elimination of ambiguities and closure of some loopholes in order to create a more coherent and thus also more effective regime.

One of the provisions needing reconsideration concerns the territorial scope of the definition of piracy. Under the existing international regime, any acts of violence, detention, or depredation committed in maritime zones within the territorial sovereignty of a coastal state are not piracy in the eyes of international law. Such crimes are defined by the International Maritime Organization (IMO) as "armed robbery against ships". Since two-thirds of modern piratical activity take place inside coastal states' territorial waters, as reported by IMB, it would be highly desirable to make the international piracy regime applicable not only to acts on the high seas and in Exclusive Economic Zone (EEZ), but to all acts committed in maritime zones, including territorial waters and archipelagic waters. This extension should be based on a system of co-ordination and Conventional consent of coastal states, without jeopardizing their sovereign rights (Jesus, 2003, p. 368).

It is also important to implement the postulate of uniformity (unitariness) of the definition of maritime piracy. This is, moreover, a postulate (and, at the same time, also an expectation) of a universal nature in the field of law. It is rightly noted by M. J. Kelly that "Perhaps a better, and more uniform, method for trying pirates would be to create a venue within the permanent International Criminal Court (ICC) in The Hague. If all the parties to UNCLOS agreed to this venue using a single definition of piracy, then it would not matter whether they were also state parties to the Rome Statute of the ICC. They could simply turn over alleged pirates and all accompanying evidence to the court, or a chamber of the court, which might happen to be sitting somewhere in East Africa or around the Indian Ocean. This would also obviate the judicial gymnastics encountered when duelling definitions of the crime are available" (Kelly, 2013, p. 42). This is an aptly worded postulate that fits into the expectations formulated both in jurisprudence, political science as well as in economy.

\section{References:}

Beckman, R. (2011). The Piracy Regime under UNCLOS: Problems and Prospects for Cooperation, CIL Workshop on International Maritime Crimes, Singapore, January 2011. Retrieved from: http://cil.nus.edu.sg/wp/wp-content/uploads/2010/10/Robert-Beckman-Session-1.pdf.

Bellish, J. (2013). A High Seas Requirement for Inciters and Intentional Facilitators of Piracy Jure Gentium and Its (Lack of) Implications for Impunity. San Diego International Law Journal, 15, 115-162. 
Bento, L. (2011). Toward an International Law of Piracy Sui Generis: How the Dual Nature of Maritime Piracy Law Enables Piracy to Flourish. Berkeley Journal of International Law, 29(2), 399-455.

Convention for the Suppression of Unlawful Acts of Violence against the Safety of Maritime Navigations, Open for Signature on 10 March 1988, Entered into Force on 1 March 1992, 1678 United Nations Treaty Series 221.

Convention of the High Seas, Open for Signature on 29 April 1958, Entered into Force on 30 September 1960, 450 United Nations Treaty Series 82.

Doby, D. (2010). Piracy Jure Gentium: The Jurisdictional Conflict of the High Seas and Territorial Waters. Journal of Maritime Law \& Commerce, 41(4), 561-580.

Dowdle, P. (2015). A Dire Need for Legislative Reform. Pace International Law Review, XXVII, 613-639.

Dutton, Y.M. (2012). Maritime Piracy and the Impunity Gap: Insufficient National Laws or a Lack of Political Will? Tulane Law Review, 86, 1111-1162.

Górski, J. (1964). Rola i zasięg zwyczajów w świetle kodeksu morskiego. Technika i Gospodarka Morska, 1, 9-10.

Gottschalk, J.A. et al. (2000). Jolly Roger with an UZI: the Rise and Threat of Modern Piracy. Annapolis: Naval Institute Press.

Hall, W.E. (1924). A Treatise on International Law. Oxford: Clarendon Press.

IMB Piracy Reporting Centre, Piracy News \& Figures. Retrieved from: http://www.iccccs.org/piracy-reporting-centre/piracynewsafigures.

Jesus, J.L. (2003). Protection of Foreign Ships against Piracy and Terrorism at Sea: Legal Aspects. The International Journal of Marine and Costal Law, 18(3), 363-400.

Kelly, M.J. (2013). The Pre-History of Piracy as a Crime \& Its Definitional Odyssey. Case Western Reserve Journal of International Law, 46, 25-42.

Matysik, S. (1971). Prawo morskie. Zarys systemu. T. I, Wprowadzenie, źródta, statek morski, armator, kapitan i załoga. Wrocław: Zakład Narodowy im. Ossolińskich.

Middleton, R. (2009). Piracy and Legal Issues: Reconciling Public and Private Interests, Conference Report, Chatham House, October 2009. Pobrane z: http://www.chathamhouse.org/sites/default/files/public/Research/Africa/011009piracy_law.pdf.

Nandan, S.N., Rosenne, S., (eds.). (1995). United Nations Convention on the Law of the Sea 1982: a commentary. Vol. 3, Dordrecht: Martinus Nijhoff.

Nyman, E. (2011). Modern Piracy and International Law: Definitional Issues with the Law of the Sea. Geography Compass, 5 (11), 863-874.

O'Connell, D.P. (1982). The International Law of the Sea. Vol. 2. Oxford: Oxford University Press.

Paige, T. (2013). Piracy and Universal Jurisdiction. Macquaire Law Journal, 12, 131-154. Protocol to the Convention for the Suppression of Unlawful Acts of Violence against the Safety of Maritime Navigations, Open for Signature on 14 October 2005, came into force on 28 July 2010.

Rothwell, D.R. et al. (2010). International Law: Cases and Materials with Australian Perspectives. Cambridge: Cambridge University Press. 
Shnider, S. (2013). Universal Jurisdiction Over “Operation of a Pirate Ship": The Legality of the Evolving Piracy Definition in Regional Prosecutions. North Carolina Journal of International Law and Commercial Regulation, XXXVIII, 473-569.

Trzciński, K. (1998). Zwyczaj i prawo zwyczajowe jako źródła prawa prywatnego. Rejent, 3(83), 156-170.

United Nations Convention on the Law of the Sea, Open for Signature on 10 December 1982, Entered into Force on 16 November 1994, 1833 United Nations Treaty Series 397.

Wiszniewski, J. (1977). Elementy prawa. Warszawa: Państwowe Wydawnictwo Naukowe. 